\title{
シート自動選別機 (オートソータ)について
}

\section{1. まえがき}

株式会社南千住製作所と東英電子工業株式会社が共 同して開発研究いたしております，この自動選別機名 称（オートソータ）の検出装置拉よびこの検出装置を 実際に応用する面で経済的な関倸機械装置の特徵と将 来性などについて，われわれの研究経過と現状を概略 ご説明申し上げ，今日わが国紙業界はもちろん国際的 飞も非常な関心がもたれて扔ると思われる，このシー 卜自動選別の問題点について皆様のご参考になり得れ ば幸いと存じます。

\section{2. 検 出 機 構}

損紙自動選別機の性能を左右するのは，第一に検出 機能である。したがってこの検出器については海外に 括いても，また最近は国内に沶いても各種の方法が研 究されすでに発表されている。

われわれは各種の検出方法中感度が優れている点と

$\begin{array}{llll}\text { 苅 部 } & \text { 誠 } & \text { 一* } \\ \text { 藤 } & \text { 田 } & \text { 正 } & \text { 和** }\end{array}$

無接触測定がでさるなどのことから光電式検出器の開 発を行なってきたが，この検出方法の難点は対照が紙 であり，紙は半透明体で表面は可成り凹凸のある散乱 面で，乙かも良紙中にも部分的に反射率または透過率 斑があり，これによって著しく検出性能が異なること である。したがって電気的光学的研究の外に紙につい ても地合斑, 光沢斑, 平滑度などの物理的性質も十分 検討しなければならない。

次に光電式検出方法には光源の光あるいは受光像を スポットにし紙面全面を走査する走查方式と，紙幅方 向に全幅にわたって光電変換素子を数個ないし数十個 列へてて各素子内に括汸る欠陷による光電变化を検出す る固定式（非走査式）のものがある。その構造, 特性, 呿よび検出感度を比較すると表 1 のようになる。

根本的には走查式は欠陥のコントラストをできるだ け大きくするため小面積スポット $\left(2 \sim 3 \mathrm{~mm}^{2} \sim 50 \mathrm{~mm}^{2}\right)$ を紙面全面に走査して高感度検出器を得ようとするも のであり，固定式は多数の光電変換素子を配列してそ

第 1 表

\begin{tabular}{|c|c|c|c|c|c|c|c|c|c|c|}
\hline & \multicolumn{3}{|c|}{ 構 } & \multicolumn{2}{|l|}{ 造 } & \multicolumn{2}{|c|}{ 特 } & 性 & \multicolumn{2}{|c|}{ 検 出感度 } \\
\hline & 可動部 & 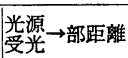 & 光 源 & 光電変換素子 & 増 幅 器 & 対震性 & 対温度 & 検出速度 & 小スポット & 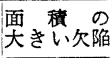 \\
\hline 固定式 & なし & $10-20 \mathrm{~cm}$ & 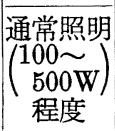 & $\begin{array}{l}\text { フォトトランジスター } \\
\text { フォトニンダクター } \\
\text { 数個乃至数十個 }\end{array}$ & $\begin{array}{l}\text { 60 80db } \\
\text { 增 幅 器 } \\
\text { 数個〜数十個 }\end{array}$ & $\begin{array}{c}\text { 影 響 } \\
\text { 少 }\end{array}$ & 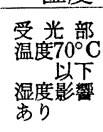 & 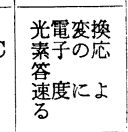 & 小 & 大 \\
\hline 走査式 & $\mid$\begin{tabular}{|} 
高速回 \\
輊部を \\
要す
\end{tabular} & $1 \sim 2 \mathrm{~m}$ & $\begin{array}{l}\text { 高輝 度 } \\
\text { 照 } \\
\text { (数kW) }\end{array}$ & $\begin{array}{l}\text { 光電子 增 倍管 } \\
\text { (受光量微少のため) } \\
1 \text { 個または数個 }\end{array}$ & 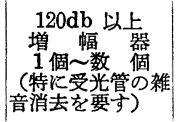 & $\begin{array}{c}\text { 影 響 } \\
\text { 大 }\end{array}$ & 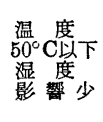 & 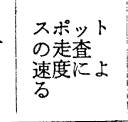 & 大 & 中 \\
\hline
\end{tabular}

の検出区域を細分して感度を上げんとするものである。 われわれは両者を比較して実用機としての基本条件 である安定性と取扱の簡便さから固定式を選び，検出 感度の向上拉よび，その他の欠点を補って，すでに抄 紙機または加工機（コーチングマシン等）での損紙自 動検出装置の実用機（名称スポットデテクター）を完 成したので，これに改善を加えて自動選別機用の検出 器とした。

\footnotetext{
* 原稿受付 39.6. 1

**（株） 南千住製作所

*** 東英電子工業株式会社
}

\section{2-1 検出器構造}

第 1 図に示す通り検出部は 2 本の螢光灯と光電変換 素子部からなり, 螢光灯は検出面付近を広範囲に散 乱光で照射し，その中央部の紙面をスリットにより $2 \sim 3 \mathrm{~mm}$ の帯状の幅で受光する高感度光導電セル (フォトコンダクター）をもらけている。最小単位 1 個の光導電セルの幅は $50 \mathrm{~mm}$ で, $50 \mathrm{~mm}$ 幅のエレメ ント 2 組でホイストーンブリッジを作り増幅器に接続 する。すなわち $100 \mathrm{~mm}$ に 1 系列の增幅器がつくわけ である。

このようにすると電源変動による光源の変化や紙の 


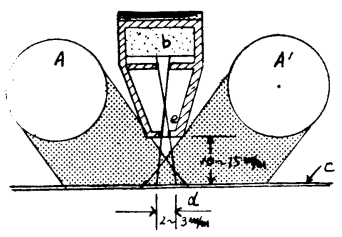

第1図検出機構の説明囲 $\mathrm{A}, \mathrm{A}^{\prime}$ 螢光灯, $\mathrm{b}$ 光電導セル, $\mathrm{c}$ 紙, $\mathrm{d}$ 紙面検出部， $\mathrm{e}$ スリット

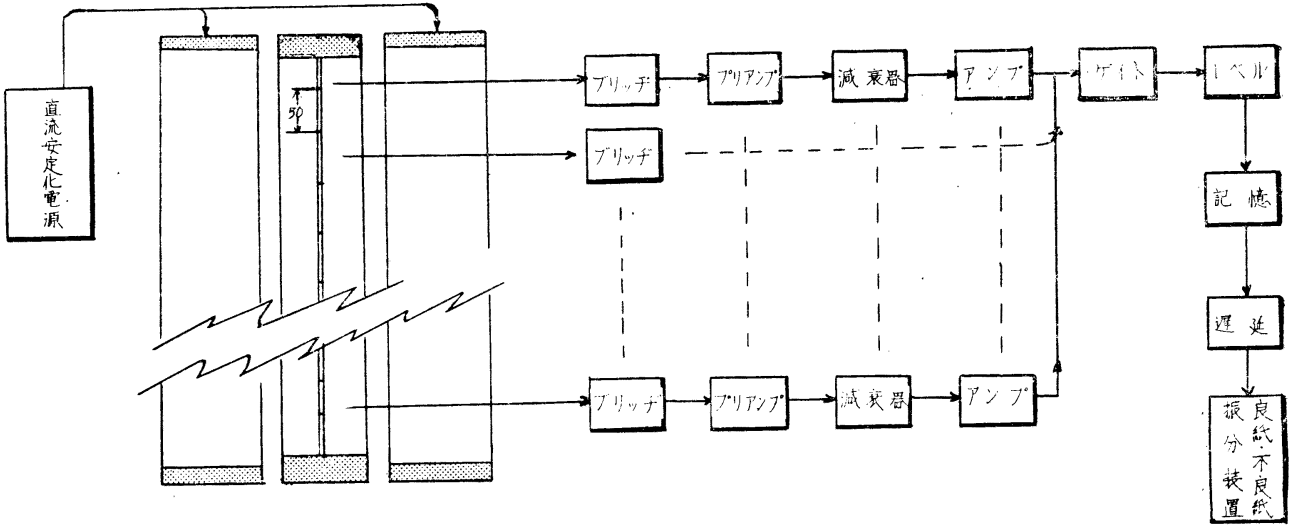

平均反射率の変化は, ブリッジにより打ち消され, 紙 面の面積 $100 \sim 150 \mathrm{~mm}^{2}(50 \mathrm{~mm} \times 2 \sim 3 \mathrm{~mm})$ 内に括忷 る欠曜による反射率の変化が，ブリッジの不平衡電流 として取り出せるのである。ブリッジからの出力は初 段増幅器を経て後, 監視用オシロスコープで増幅器毎 に各々の感度が一定になるよう調節する減衰器を通る。 また紙の通過初めおよび終わりには必ず大きなパルス が生ずるので，これは別の光電セルにより消去し，紙 通時のみ動作するためゲイト回路を付している。レベ ル調節は紙の平均反射率斑によるノイズ電圧を消去す

(1)

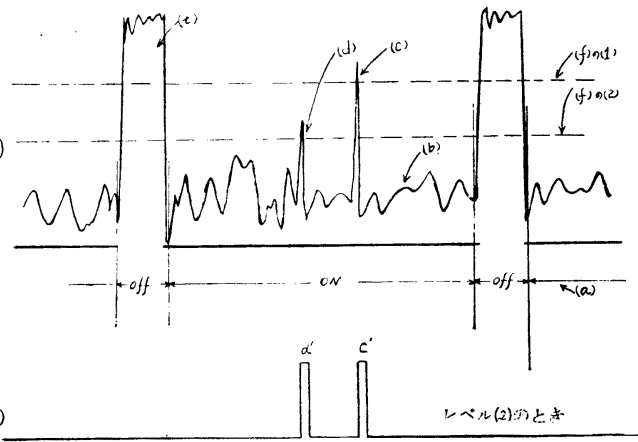

(3)

レデル()のとき

第2図増幅器出力の波形例 a ゲイト動作，b 紙斑によるノイズ， c 大欠 陥信号， d 小欠陥信号， e 紙面通過前後のノ イズ，fレベル調節電圧
ると共に欠陥によるパルス電圧の大小を利用し，電圧 值を調節することで検出すべき欠陥の大きさを選択す ることがでさる。

第 2 図(1)は動作中の増幅器出力波形の一例で，ゲイ トおよびレベルを通過した後のパルス波形は同図(2)(3) のようになる。(2)はレベル電圧を低く設定したときで 小欠陥も検出信号になり，(3)はレベル電圧を高く設定 し大欠陥だけしか検出しないものである。

このように不良紙が検出部を通過するとレベル調節 後の回路にパルスが出る。このパルスは記憶回路，遅 延回路を経て，不良紙が「良紙不良紙振分装置」に入 る時振分機が作動し，不良紙が振分機を通過すると元 にもどる。

\section{2-2 検出器の特性}

地合斑（反射率斑）による影響

本機の検出性能にこの影響が最も大きいことは初め に記した通りで，第 2 図(1)の増幅器出力波形を見ても 地合斑によるノイズ電圧が低くければ，レベル電圧を 低く設定して微小欠陥パルスを検出することがでさる わけである。幅方向の地合斑を平均化するには光導電 セルの幅を広くすれば良いが，欠陥パルスも小さくな って感度が低下する。また幅を狭くすると検出部の数 が増加して装置が大さくなり過ざる。これらの妥協点 を見出すため，われわれは先に開発した地合測定器 （名称フォーマスター）によって各種紙葉の地合斑を 測定したところ，一般に上質紙では抄紙機の流れ方向 で $3 \sim 20 \mathrm{~mm}$ の斑が多く, 幅方向については 20〜50 $\mathrm{mm}$ のものが最も多いことが判明した。この結果と先 
の欠陥パルスの感度, 検出部数を勘案して光導電セル の幅を $50 \mathrm{~mm}$ に決定したのである。またスリット幅 は広くすると著しく感度が劣化するので $2 \sim 3 \mathrm{~mm}$ に した。

いずれにしても地合斑は紙自体によるものなので反 射斑の少ない厚手アート紙などとマシン仕上げ上質紙 とでは検出性能に著しい差異が生ずる。

温度による影響

使用している光導電セルは $70^{\circ} \mathrm{C}$ まで添とんぞ影響 がない。セル部の温度が $70^{\circ} \mathrm{C}$ を超光ると破損するの でその場合は冷却装置が必要になる。

湿度による影響

光導電セルは湿度に対しては問題になる。そこでセ ルの表面技よびケースをガラス被膜で完全シールしこ の影響を除いてある。

震 動の影響

投受光器間距離が比較的短かいので走查式の検出器 汇較べて振動の影響は著しく少ないが，衝撃によって はパルス発生をするのである程度の防震は必要である。

照度变化による影響

光導電セルは照度により注添直線的浜抗変化をす るので照度によって電流の増減がある。しかし電圧パ ルスとして取り出しているので電流と光導電セルの抵 抗値との積は注ぼ一定で感度は汪とんど変化がない。

たと党ば光導電セルの入射光が 100lux のものが :50lux になったときの感度低下は $10 \%$ 以下である。

\section{速度の影響}

光導電セルは光電管などと較べて光变化に対する抵 抗变化に時間遅れがある。そのため平均入射光量を適 当にしたり，七ルの素材の配合を研究して最も時間途

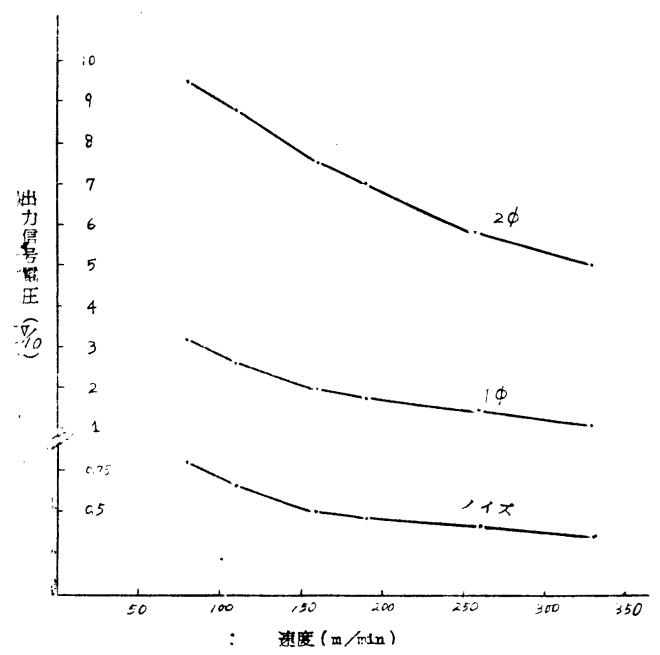

第 3 図速度と出力信号電圧
れの少ないものを使用しているが，それでも立ち上り 時間, 数 $\mathrm{ms}$ は避けられない。したがって紙送り速 度が増大した場合当然検出感度は低下する。しかしこ の時間遅れは紙斑によるノイズの減少にもなるので, 前に述ベたレベル電圧を調節することで可成り補らこ とがでさる。第 3 図は各污点スポットの速度に上る検 出パルスの変化を表わしたもので，信号対ノイズ比は $80 \mathrm{~m} / \mathrm{min}$. のものと $300 \mathrm{~m} / \mathrm{min}$. のものでわずかの低 下である。

むしろ速度が增大することによって生ずる検出面の 振動によるノイズを注意しなければならない。

\section{色の 影 響}

欠陥の色によって第 4 図のごとさ色感度差がある。 欠陥が赤〜黄のように波長の長い色が多い場合には光 源波長, 执よび, 光導電セルの色感度特性を変わった ものを使用するかフィルターの使用により感度を向上 することができる。

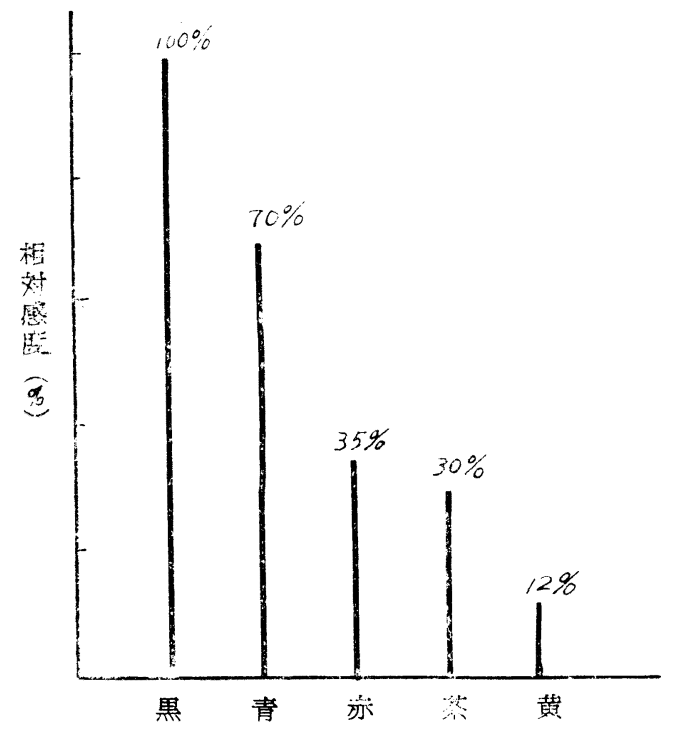

第4図色 感変 差

\section{2-3 検出器の性能}

本機の検出感度は前述したごとく微小黑点に対して は，受光面積が広いので低くなる。これを補うため欠 陥パルスの立ち上り公配を微分し，これを検知して感 度を上げている。しかし実際に不良紙の欠陥は比較的 白黒のはっきりしない可成り広面積 ( $5 \mathrm{~mm} \phi$ 以上) のものが多く, 微小スポットを対照に感度を上げる之, 過選別する抢それがある。

実際の検出感度については紙の種類と, 久陥の種類 により異なるので一概にいらことはできないが，試作 の「オートソータ」で試験した結果の一例を次に示す。 
紙質 アート紙 $90 \mathrm{~kg} /$ 連

速度 $180 \mathrm{~m} / \mathrm{min}$

検出感度

\begin{tabular}{|c|c|c|}
\hline 污 点 感度 & 良紙過選別 0 & 良紙過選別 $3 \%$ \\
\hline $1.8 \phi \mathrm{mm}$ 黑点 & $100 \%$ 検出 & $100 \%$ 検出 \\
\hline $1.3 \phi \mathrm{mm} \quad$ II & $95 \% \quad \prime \prime$ & $100 \% " 11$ \\
\hline $1.0 \phi \mathrm{mm}$ & $87 \% \quad \prime \prime$ & $95 \% \quad 11$ \\
\hline $0.8 \phi \mathrm{mm} \quad$ " & $55 \%$ & $72 \%$ \\
\hline
\end{tabular}

以上検出機能の概要であるが，不良紙の久陷の中に は光電式では検出困難なものもあるので, 目的によっ て他の検出方法を併用する必要考考方れる。

また一般に良紙と不良紙の選別限界が明確でないこ とが多いので，多少良紙が不良紙中に含まれる位に感 度を上げて, 不良紙群を再選別するなど, 使用方法に ついても考虑が必要であると思う。
れの検出方式を装置構成の基本と致している。

け) 単個の巻取紙ロールまたは抄紙機（コーター，各 種ペーパーコンバータープロセス）ラインより連続 し出てくる紙匹（ウエブ）を直接電子検出装置で検 別し，プロセスライン中のシートカッタと連動して リジェクトゲート（選別振分けゲート）を操作し高 速度で連続自動的に選別する方法。

この場合特にウェプの性質（セロファン，織布， ビニールフィルムなど）いかんで検出方法が種々変 わっても, 切断機, 振分け装置, オバーラッピング, 堆積レーボーイなどが高速の処理能力を十分発揮す る必要があると考えられる。

( 前項と同様連続して出てくるウェブを高速度で連 続切断し流れ出てくるシートを 1 枚每に枚葉選別機 之同様な装置をもって自動的に選別する方法。

この方式の特徴は既設の切断機を利用したり，ま た枚葉シート選別機の枚葉フィダーが単に切断機と

\section{3. 機械装置}

シートの選別方法を仮に直 接および間接の二分類で検討 すると次の通りになる。

\section{3-1 直接選別式}

(1) 従来各工場で行なわれて いるリールからロータリー カッターで切断した枚葉シ ートを全量選別作業員によ ってハンドソートまたはマ シンソートする方法。

このマシンソートとは印 刷機械等で使用されている 堆積紙用枚葉フィダー（紙 差機）十シートコンベヤー テーブルーシート振分けゲ

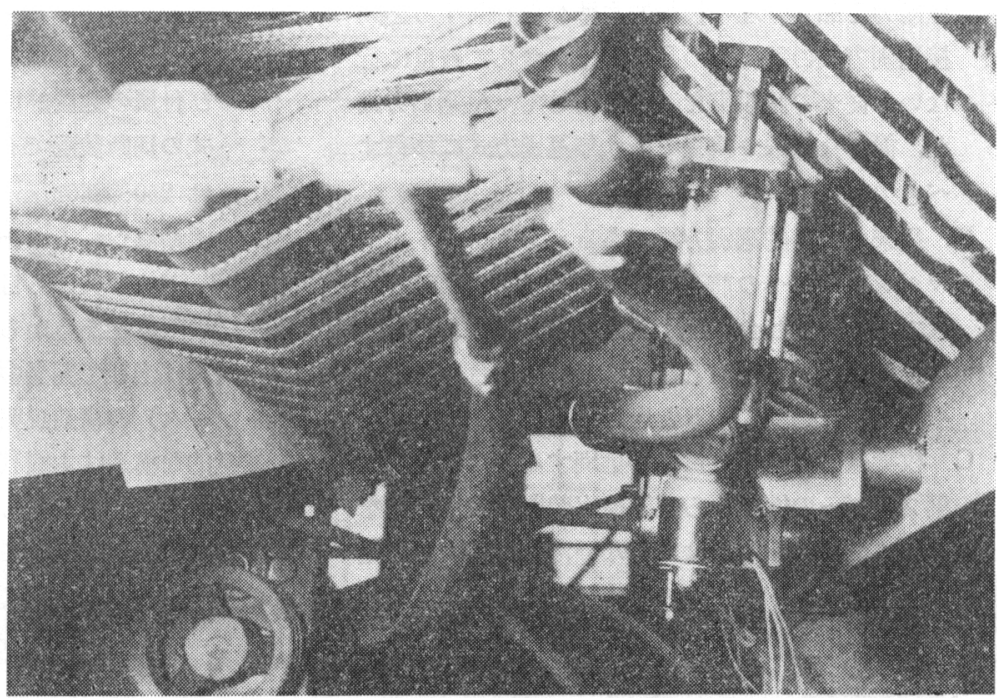

第 5 図 選別振分けゲート部

入れ替っただけであるから検出，振分け，オーバラ ップ, コンペヤー，レーボーイなどの諸装置はその ままで使用でき，またカッターと連動する複雑な電 子頭脳回路も必要がなく, 特にカッター損紙トラプ ルも含めて完全な選別ができる利点がある。

\section{3-2 間接選別式}

抄紙機，各種コーター，スーパーカレンダなどの巻 取リール直前で電子検出装置をもって検別し，自動的 に巻取ロールに各種のマークを施し，巻取ロールの直 接選別分類を行ない, しかるのら従来の復数アンリー ルスタンドとシートカッター間に簡単なマーク検出部 を設けて，カッターと連動して損紙および良紙を含む 
積層シートを間接的に粗選別し，これより再度枚葉選 別機で直接精選別するか，あるいはマークを元にして ハンドソートするか，または簡単なマーク検出機を利 用した間接式枚葉選別機が使用される。同様な考兄で マーキング巻取ロールからシングルシートを簡単なマ 一キング検出機を利用して間接的港高速選別すること も可能である。したがってこの間接選別方式の発展は シート自動選別機の将来について極めて興味深い所で あると思う。

以上の各シート選別方法を比較して，シートの自動 選別機（オートソータ）が現状で具備せねばならない 機能上の要点と, 併せて $2 \sim 3$ の補足事項を加光てピ ックアップし取りまとめると

A シート選別の手段を決定するにはまず現状の工 場が選別を必要とする生産紙質和よび処理量, 将 来性などの総合経済効果を入念にチェクリストア ップすべきだと感じる，現状わが国製紙工業の生 産能力之品質管理の技術的水準から判断すると間 接選別方式の前向きの品質管理をさらに厳重に行 ない, 従来の諸設備を改善活用して, 粗選別方式 か，簡単な抜取り検查で済す無選別方式に移行す ベきであろう。

B 従来の人為的選別方法であるハンドソートより マシンソートへの前進は根本的な改善に困難な時 代であるが，社会環境より考兄て今後もなお貴重 な選別熟練者の経験と技能は特殊な場合の粗選別 や精選別に必要であると思われる。

C 枚葉紙より直接全量自動選別する方式は現状枚 葉フィダーの性能から電子検出装置の検別能力を フルに活用することはでさない，しかし人手不足 の現在, ハンドソートの確率拉よび能力に比較す れば 1 名当たりの選別量で $4-5$ 倍の差があり, また本機取扱い者は特別の熟練を必要としないな ぞの利点や，特に選別効果の再現性と計測確率を 考光れば粗選, 精選に今後多いに利用すべきであ る。

D マシンラインでウェブより切断シートを高速度 で1枚毎に連続自動選別する方式は, 当然りジエ クトゲートコンベヤー, シートオバーラップコン ベヤーおよび，復式レーボーイを付属した高速度 自動連続切断機が必要であるが, 紙の腰が弱い $50 \mathrm{~g} / \mathrm{m}^{2}$ 前後の薄紙処理の場合では最高 $120 \mathrm{~m} / \mathrm{min}$ $\sim 180 \mathrm{~m} / \mathrm{min}$ が実用速度の限界であろら。したが ってマシンラインでのウェブより直接シートの自 動選別装置を考学る場合はウエブの材質と生産速 度を十分考虑する必要がある。
E 間接選別方式で数本掛アンリールスタンドと従 来のカッターを使用し積層シートにテープマーカ 一を色分け挿入して粗選別する方式も現有設備を 生かして使用寸る 1 万法であるが，広蝠マシンの ダブルカッターで高速に各種のシートサイズを生 産し，これを間接的に粗選別する方式はシートの 生産性を阻害しまたカッター自体で生じやすい損 紙トラブルを合わせ考えれば，間接選別方式の効 果を十分発揮し得ない所など実情に則して今後と も慎重に検討すべさであろう。少なくとも現状の 業界事情よりシートの生産性向上を具体的汇行な らとすれば, 現有のシートカッターにはりジェク トコソベヤー, ラッピングコンベヤー, ジュアル レーボーイを付属せしめる改良を積極的に行なわ れるべきである。

F 前述のごとく今後急速に開発研究が進む間接選 別方式で，シートの高度な生産を考光れば特に選 別を必要とするシートサイズの最大寸法を元にし た合理的な専用の高速度連続シートカッターおよ び付属の装置が出現するであろう。しかしこの方 式の切断装置でもな挆経済的に安定した最高速度 は $250 \sim 280 \mathrm{~m} / \mathrm{min}$ が限度であるう。なぜか？

“積層シートのオバーラップコンベャーおよびレ 一ボーイ突出し自動紙揄へ堆積方式㙨能上の処 理限界があるから”

附図は当社で開発中の各種シート自動選別機（オー トソータ）の構造説明用参考図であります。これらの 総括的な構造は本機利用の目的から取扱い容易で, 極 めて単純，経済的なものでなければなりません。した がって図示のごとくであり機械的要部の説明は省略致 します。

\section{4. 結 び}

以上試作した自動選別機（オートソータ）について ユーザ各位のご理解あるご支援を賜り各種の試験を実 施する事ができましたので，実用機設計の貴重な資料 を得られたことを厚く感謝するとともに今後もご指導 ご鞭撻を得て一層高精能で経済的な選別装置を完成し たい所存であります。

（怢式会社南千住整作所 東京都荒川区南千住 8 の 80 ) （東英電子工業株式会社＼cjkstart東京都大田区上池上町 962 ） 


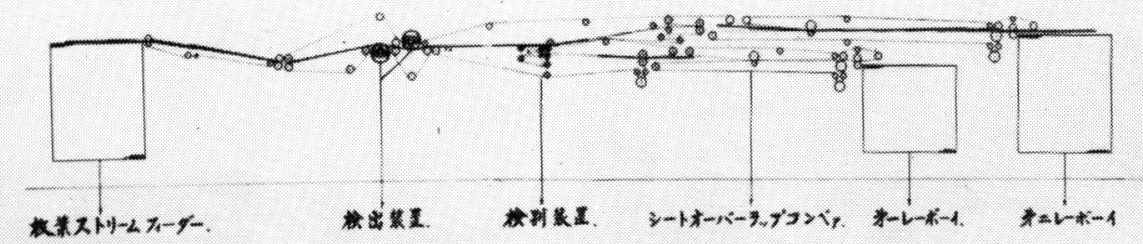

第 6 図 シート自動選別機（オートソータ）枚葉フィダー式ダイヤグラム

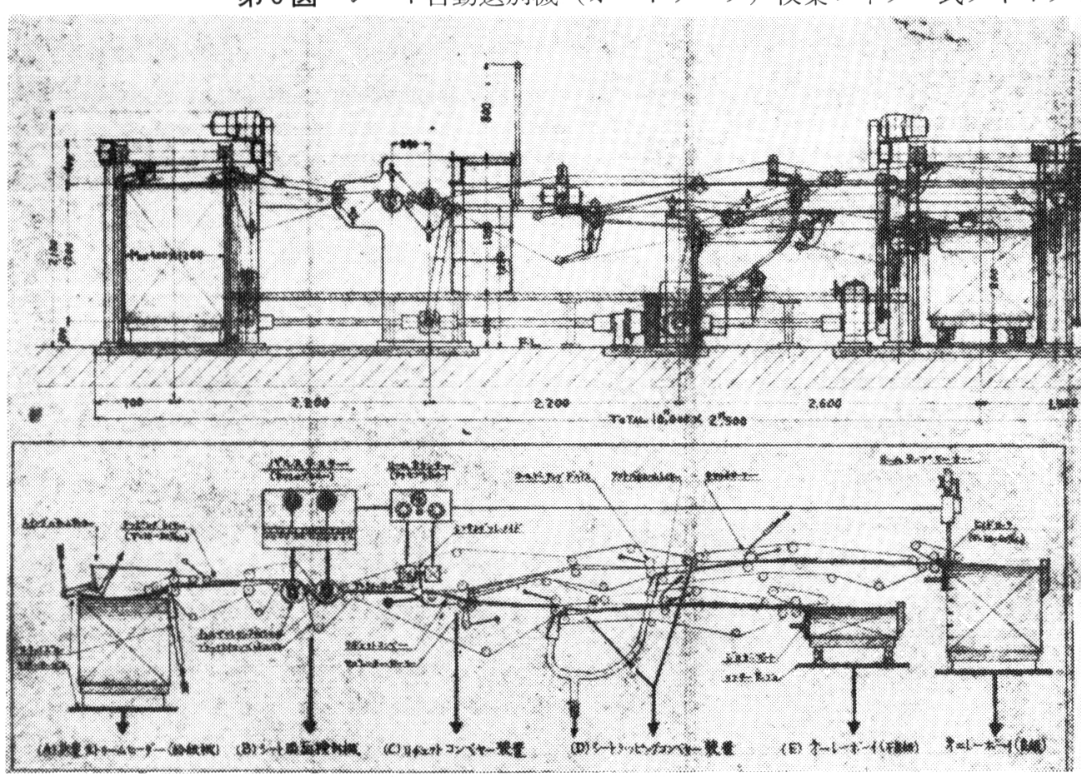

第 7 図 シート自動選別機（オートソータ）枚葉フィダー式
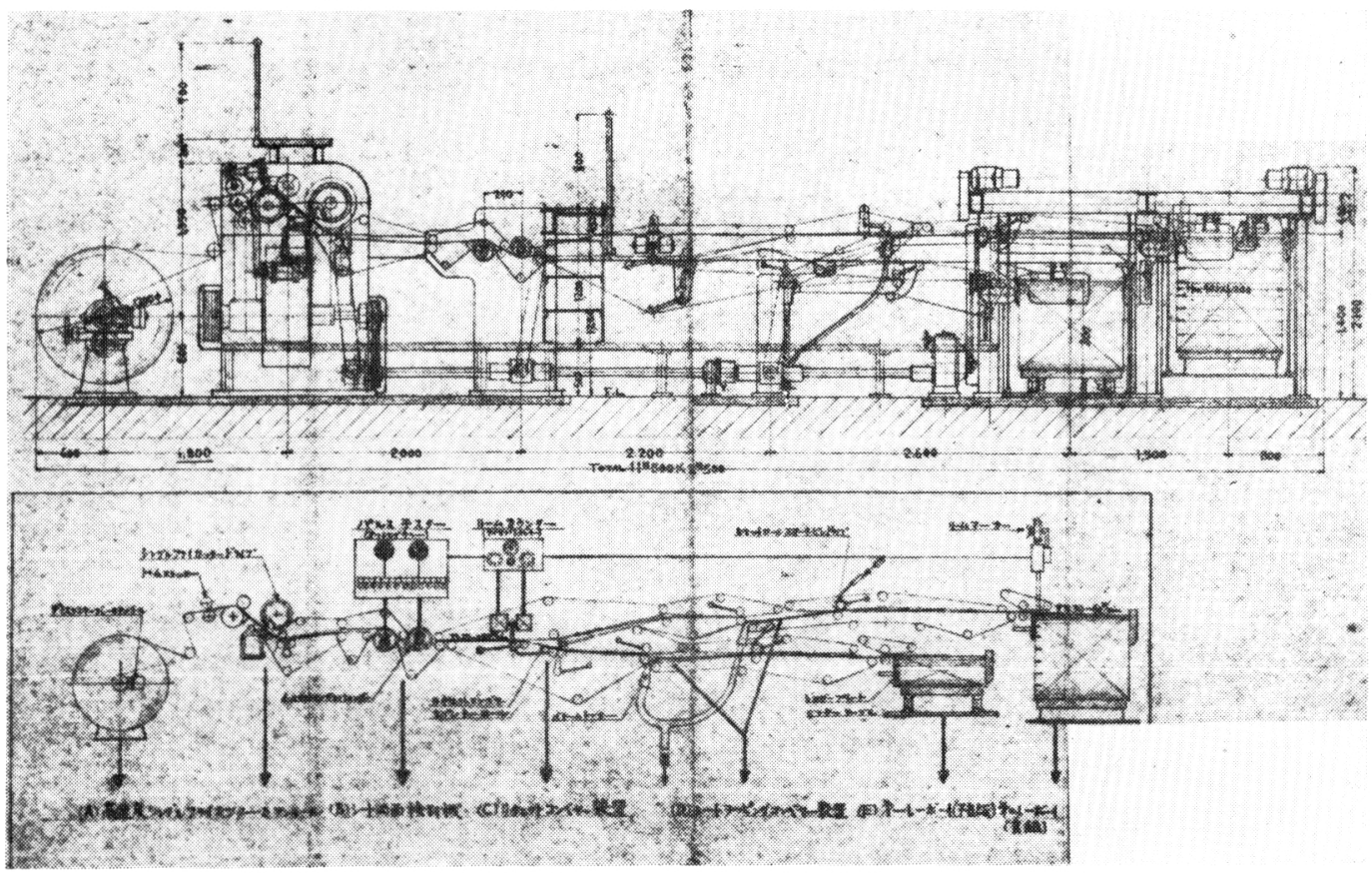

第 8 図 シート自動選別機（オートソータ）A型巻取ロール，カッター式 


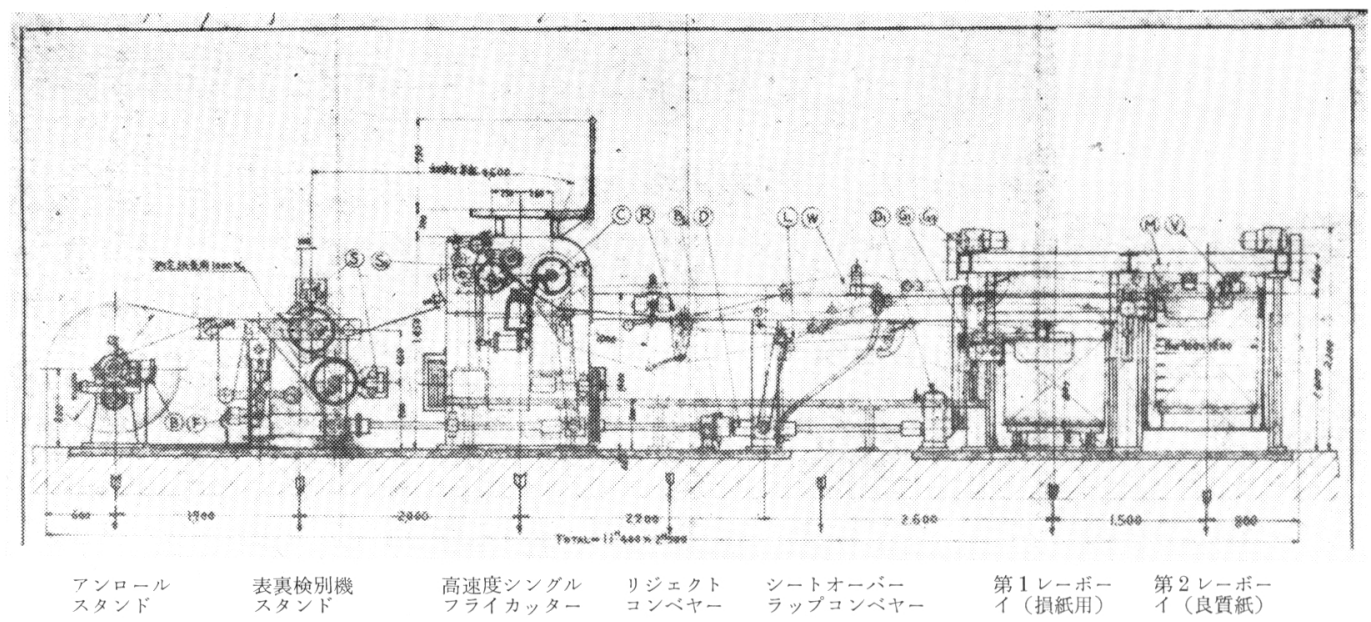

第 9 図 シート自動選別機（オートソータ） B 型巻取ロール，カッター式

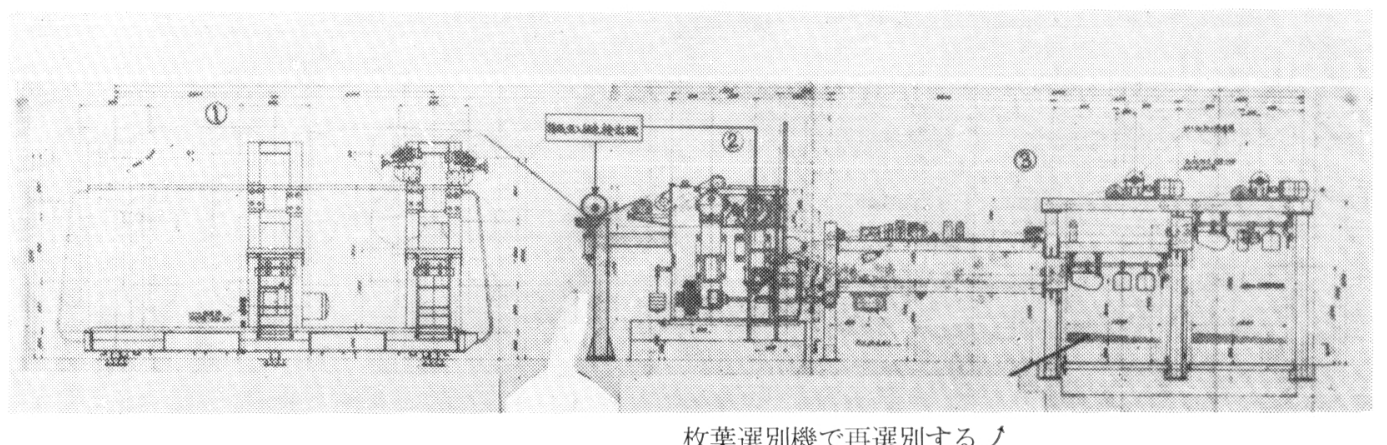

第 10 図 シート自動選別機（オートソータ）間接選別式ロンテニアスカッター

\section{ご期待を乞う!}

\section{紙ルパプ事典 10月に発刊予定}

昭和 36 年夏より紙パルプ用語辞典編集委員会を結成し 4 力年にわたり審議し て来ましたが，本年 5 月に審議を終り，出版を金原(か㸚はら)出版にたのみ，た だいま組版中および校正中で，今秋 10 月頃㤕版できる見とおしがつきました。

紙パルプ業界において，紙パルプに関する事典の出版をのぞむ声は，長い間， 聞かれていましたが, さて昭和 36 年作成にかかりましたところ, なかなか難事 業のため，ついに予定の年月を過ぎましたが，審議に慎重を期しただけに，みな さまのご期待に沿えるものができます。

\section{語数 約 5,000 A 5 判 上製本 予定価格 1,500 円}

英語より日本語訳および説明をさがす方式ですが，巻末に日本語から英語のさ がせる索引をつけますので，英和と和英との両用に使えます。 